\title{
The Impact of the International Accounting Convergence on Income Smoothing in Brazillian Companies
}

\author{
Roberto Carlos Klann ${ }^{\dagger}$ \\ Blumenau Regional University- FURB \\ Ilse Maria Beuren ${ }^{\Omega}$ \\ Paraná Federal University-UFPR
}

\begin{abstract}
In Brazil, the convergence to IASB standards began in 2008 with the entry into force of the Law n. 11.638/07. This study has as objective to verify the influence of the convergence process to the international accounting standards in income smoothing level in Brazilian companies. The study has a quantitative approach, based on the model of Barth, Landsman and Lang (2008), was carried out from the financial statements of 133 companies in the period of 2005-2007 (pre-IFRS) totaling 344 observations, as well as 106 companies in the period of 2010-2012 (post-IFRS), totaling 289 observations. The financial statements were extracted from Thomson ONE Banker website. In the data analysis, were applied statistical techniques of multivariate linear regression, $\mathrm{F}$ test and Pearson correlation. The results show a rising in income smoothing levels after convergence. It is concluded that the effectiveness of the process of convergence of accounting standards of the country to international standards, in order to get better quality of accounting information, does not depend only on the convergence of accounting standards.
\end{abstract}

Keywords: International accounting convergence. IFRS. Earnings management. Income smoothing.

${ }^{\dagger}$. $\mathrm{PhD}$ in Accounting and Business Administration by the Post-Graduated Program in Accounting at Blumenau Regional University - FURB Institution: Professor at the Post-Graduated Program in Accounting at Blumenau Regional University- FURB - SC - Brazil

E-mail: rklann@furb.br

\footnotetext{
${ }^{\Omega} \mathrm{PhD}$ in Controlling and Accounting by São Paulo University - FEA/USP Institution: Professor at the Post-Graduated Program in Accounting at Paraná Federal University - UFPR - PR - Brazil

E-mail: ilse.beuren@gmail.com
}

Note from the editor: This article was accepted by Emerson Mainardes 


\section{INTRODUCTION}

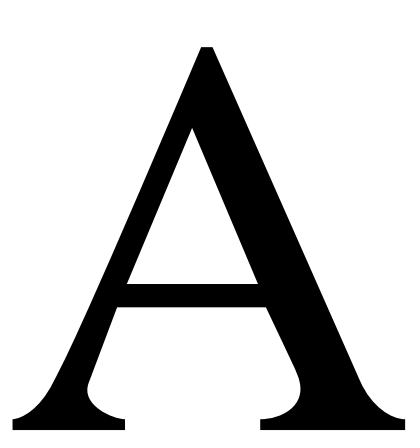

ccounting, as the main provider of information of companies, plays a key role in trade and financial transactions. The differences between accounting standards of the various countries represented an obstacle to this process as it hindered business language by the lack of uniformity in the assessment of the economic events of companies.

The accounting standards convergence of each country to international accounting standards is important to mitigate these barriers. In this sense,

the International Accounting Standard Board (IASB) played a key role, to develop a set of high quality accounting standards, which could serve as a global standard reference for the preparation of financial statements, called International Accounting Standards (IAS) and International Financial Reporting Standards (IFRS).

In Brazil, this process of convergence to the IASB standards has as key milestones the creation of the Comitê de Pronunciamentos Contábeis (CPC) in 2005, the Instruction N. 457/07 of the Brazilian Securities Commission (Comissão de Valores Mobiliários - CVM), which led to public companies the preparation of consolidated financial statements under IFRS from 2010, in addition to the Law N. 11.638/07, which amended several provisions of Law N. 6.404/76.

The convergence of local accounting standards to the IASB standards aims to reduce the distortion of information reported by companies from an international trade scenario and search for developing foreign capital flows. It is expected, therefore, a reduction in information asymmetry between the various users of financial information, such as investors, analysts, business partners and other stakeholders in different countries.

The convergence of accounting standards at the international level motivated the research studies on the impact of this process in the financial statements. Some of these studies address the impact of IFRS on the capital market (ASHBAUGH; OLSSON, 2002; BENEISH; YOHN, 2008), others investigate its effects on the cost of capital injections (ERNSTBERGER; VOGLER, 2008), the protection to investors (RENDERS; GAEREMYNCK, 2007). Other investigated the adequacy of local levels of GAAP to IFRS (DING; SU, 2008). There is still others that examined the economic consequences of the adoption of IFRS (CHRISTENSEN; LEE; WALKER, 2007; DASKE et al., 2008). 
Convergence to IFRS also raised queries related to earnings management (GR), but the results of international studies disagree on the effects of convergence on GR levels. Several studies show that certain contextual characteristics of countries can influence the effects of convergence on the GR, as investor protection mechanisms (DYCK; ZINGALES, 2004; RENDERS; GAEREMYNCK, 2007), legal system based on common law or code law (LEUZ; NANDA; WYSOCKI, 2003), local accounting standards based on rules (VAN Tendeloo; Vanstraelen, 2005; GONCHAROV; ZIMMERMANN, 2006), access conditions to capital market (JEANJEAN; STOLOWY, 2008), more effective system of mandatory adoption of IASB standards and greater regulation of corporate governance (CHEN et al., 2010).

In Brazil, Santos et al. (2011) investigated whether the enactment of Law N. 11.638/07 changed the degree of accounting conservatism, measured by Basu's model, of nonfinancial Brazilian companies, between the first quarter of 2005 and the third quarter of 2009. These authors did not found significant effects, but point out that their results are preliminary, given the limitation of the sample. Grecco (2013) using the Modified Jones Model, found no changes in levels of earnings management of the 361 nonfinancial Brazilian companies from 2005 to 2011. Rosa and Tiras (2013) investigated aspects of the economic environment in which were drawn the financial statements and the potential for earnings management in Brazil. These authors suggest to Brazilian researchers examine aspects of the Brazilian economic environment, as the recent attractiveness of foreign investments, corporate structure and the effects of inflation on management practices. They point out that not all the earnings management models used in international studies are suitable to Brazilian reality.

Studies on the subject that analyze companies from various countries, such as Yoon (2007), Barth, Landsman and Lang (2008) and Chen et al. (2010) do not show a comparison of the effects of convergence between countries' GR, separating groups in these countries, e.g., in accordance with their contextual characteristics. To investigate the influence of the international accounting convergence process in Brazilian companies, in relation to income smoothing, a form of GR, can contribute to a better understanding of the benefits of convergence, in terms of quality of accounting information.

This gap involves checking the extent to which convergence to the IASB standards influences of GR in Brazilian companies included in a specific environment, characterized by a stock market expanding, a legal system based on code law and local accounting standards by 2007 based on rule instead of principles. Thus arose the following research question: What 
is the influence of convergence with international accounting standards in income smoothing level in Brazilian companies? The objective of the study is to assess the influence of convergence with the IASB standards on the level of income smoothing in Brazilian companies.

Despite expectations about the effects of the international accounting convergence process, are still incipient studies on the subject in Brazil. As this convergence process in Brazil is recent, it is justified to study that seeks to identify its influence in the GR of the companies through the income smoothing approach. The improvement over the research of Barth, Landsman and Lang (2008) stems from the fact of been considered a distinct field of study, with different contextual characteristics and the outstanding economic importance of Brazil, besides considering a longitudinal period ex-ante and ex -post to convergence.

\section{EARNINGS MANAGEMENT}

In addition to term earnings management (gerenciamento de resultados - GR), Paul (2007) also cites the income smoothing, conservative accounting for reduction of current profits for the sake of future profits or big bath accounting and make-up of financial statements or window dressing.

Two of the most found definitions of GR in academic, international or national literature, are presented by Schipper (1989) and Healy and Wahlen (1999). Schipper (1989, p. 92) considers the GR as a "purposeful intervention in the foreign disclosure process, with the intention of obtaining some private gain." With this definition, Schipper limits the discussion of GR to external disclosures, excluding managerial accounting reports.

For Healy and Wahlen (1999, p. 368), the GR occurs when administrators use as judgment in the reported financial information and decisions relating to operating activities, in order to "change financial information, or mislead some investors on economic performance the company or to influence contractual outcomes that depend on reported accounting numbers."

In these perspectives, the GR implies modification of the reported financial information, in order to gain some individual manager, or to allow the company to present a more favorable situation to its stakeholders. Santos and Paul (2006, p. 16) point out that "the possibility of distortion of accounting information usually comes from the existence of alternative criteria for recognition, measurement and/or disclosure within the accounting system." It gives opportunity to administrators choose one of many meaningful alternatives to 
portray the information in the most convenient form and may distort the analysis of business performance.

The motivations or incentives for GR practice have been the subject of several studies. Watts and Zimmerman (1986), from the Positive Theory approach, developed three hypotheses to guide studies on the explanation of the adoption of certain accounting practices by companies: incentive plan, indebtedness level and political costs. Healy and Wahlen (1999) reported three incentives should be based on empirical research in GR: capital markets, contractual incentives and regulation. Martinez (2001) also adds the political costs in regulatory reasons for the existence of GR.

Martinez (2001) states that there are different types of GR, depending on the motivations involved in the process, but highlights three main types. The modality of the target earnings consists in managing to achieve certain predetermined profit targets, which may be higher or lower than earnings. In income smoothing, the objective is to reduce the variability of results, remaining stable results in a certain level. In conservative accounting (big bath accounting), the company worsening its current income in order to improve future incomes.

Several models or methodologies for investigation or detection of GR by the companies are found in literature, in qualitative or quantitative models. According to Martinez (2001), the quantitative approach is based on three approaches: distribution of frequency analysis of specific accrual and analysis of aggregate or total accrual.

The uniformity in the frequency distribution of income was associated with GR by Burgstahler and Dichev (1997). It consists of the empirical evidence of a small number of companies that have small losses and a large number of companies with small profits. The main advantage of this methodology is not having to estimate accruals, however, does not analyze how the GR was done (TRAPP, 2009).

The analysis of specific accruals, according to Trapp (2009), aims to analyze the behavior of certain classes of companies or specific accounting accounts. It requires large number of observations. The methodology of the aggregate or total accruals was first used by Healy (1985). The objective is to estimate the discretionary component of the accruals. Total accruals are divided into: Discretionary and non-discretionary. The discretionary part of the accruals is manageable, or rely on the judgment of the manager. 


\section{MANAGEMENT RESULTS AND CONVERGENCE TO IFRS}

The relationship between GR and the convergence of accounting standards at the international level is discussed in several studies, but the results are not similar. Some found no significant differences between the reports on IAS/IFRS and reports in local GAAP (VAN TENDELOO; VANSTRAELEN, 2005; JEANJEAN; STOLOWY, 2008; ELBANNAN, 2011). Others point increase in GR after the adoption of IASB standards (GONCHAROV; ZIMMERMANN, 2006; PAANANEN; LIN, 2009).

Jeanjean and Stolowy (2008) observed that the GR levels of UK and Australian companies did not decrease after the adoption of IFRS. In French companies, there was an increase in GR after the convergence to IFRS, which can increase the information asymmetry between managers and external users of financial statements of these companies.

By studying the adoption of IFRS by Egyptian companies, Elbannan (2011) found no significant evidence of reduced GR after the process of convergence. He attributes these results to the lack of conformity between the preparers of financial statements, inappropriate regulatory mechanisms, poor infrastructure accounting in that country and inadequate training of professionals.

According to Van Tendeloo and Vanstraelen (2005), Goncharov and Zimmermann (2006) and Jeanjean and Stolowy (2008), the process of convergence to the IASB standards, more flexible, because they are based on principles rather than rules, may result in increased GR levels, particularly in countries with accounting standards based on rules, with weak stock market and little protection to investors. This combination of factors can lead to a GR setting higher under the IASB standards, in relation to local accounting standards. In this sense, it was elaborated the research hypothesis as follows:

$\mathrm{H}_{1}$ - the process of convergence with international accounting standards increased the earnings management in Brazilian companies.

On the other hand, there are studies that point to improvement in the quality of reports based on IAS/IFRS (ASHBAUGH; PINCUS, 2001; YOON, 2007; BARTH; LANDSMAN; LANG, 2008; CHRISTENSEN; LEE; WALKER, 2008; CHEN et al., 2010; IATRIDIS, 2010; IATRIDIS; ROUVOLIS, 2010).

Yoon (2007), when analyzing the accounting convergence process in 41 countries, found some evidence of a positive association between the convergence of accounting standards and the improvement of accounting quality. One of the proxies used was the quality 
of accruals related to GR. Christensen, Lee and Walker (2008) observed in their research a quality improvement with the adoption of IFRS only for companies with incentives to adopt IASB standards.

Barth, Landsman and Lang (2008), researching companies from 21 countries, found that those that adopt IASB international standards have less evidence of GR, more timely loss recognition and higher value relevance to the financial statements. Iatridis (2010), in search of the adoption of IFRS in British companies, obtained the same results as Barth, Landsman and Lang (2008).

However, the results of study and the Iatridis and Rouvolis (2010) in Greece companies show a small increase in the GR soon after convergence and reduction in the following periods. In general, there noted improvements in the quality of accounting statements with the adoption of IFRS.

When researching companies from 15 countries of the European Union, Chen et al. (2010) found a reduction of GR levels after the adoption of IFRS. These authors add that the improvement of accounting quality is attributable to IFRS, rather than changes in the managerial incentives, institutional characteristics of the capital market and general business environment.

Furthermore, based on the results of research Barth, Landsman and Lang (2008), Iatridis (2010), and Iatridis and Rouvolis (2010), the high requirements of disclosure and the quality of financial reports required by the IASB standards lead to reduction in GR levels, especially in countries with strong stock market and robust mechanisms for the protection of investors. In this perspective, we elaborated the following research hypothesis:

$\mathrm{H}_{2}$ - the process of convergence with international accounting standards decreased earnings management in Brazilian companies.

Barth, Landsman and Lang (2008) weigh in their study that the results of the companies may be influenced by other factors not attributable to the financial reporting system of the entity, reflecting the GR measures. The authors used factors such as size, sales growth, percentage change in the preferred shares, debt ratios, cash flow and auditing, as control variables to ensure the reliability of the metric used to GR.

It appears that the convergence of accounting standards at the international level, with the adoption or adaptation to the accounting standards of the IASB, may result in greater or lesser flexibility in comparison with the local rules of the IASB. This process can provide, 
according to some studies presented here, the GR, considering the opportunistic behavior of the agent (preparer of financial statements).

\section{RESEARCH METHOD AND PROCEDURES}

This section presents the population and sample of the research, as well as procedures for collecting and analyzing data.

\subsection{POPULATION AND SAMPLE}

The population of the research is made up of Brazilian companies listed in the Thomson ONE Banker (http://banker.thomson.com) database, totaling 364 companies. The criteria for sample selection was that the company present values for all the variables studied in both study periods (2005-2007 and 2010-2012). Based on this criterion, it was identified 123 companies, totaling 369 observations in each period. Finally, during the analysis, 12 observations were excluded, classified as outliers in the pre-convergence period, resulting in a final sample of 357 observations during this period. In the post-convergence period, were excluded 34 observations classified as outliers, resulting in a final sample of 335 cases. Were classified as outliers observations above three standard deviations, obtained directly by SPSS 20.0 software.

\subsection{PROCEDURES FOR DATA COLLECTING AND ANALYZING}

The study used as proxies of GR three measures related to income smoothing, based on the model adopted in Barth, Landsman and Lang (2008). The metrics used to measure GR levels of Brazilian companies in the pre-convergence period (period 1) and post-convergence period (period 2) are described below.

Metric 1: Variability of changes in net income $(\Delta \mathrm{NI})$

Dependent variable:

$\Delta \mathrm{NI}$

$$
\Delta N I=\left(\frac{L O}{A O_{n}}-\frac{L O_{n-1}}{A T_{n-1}}\right)
$$

Where:

LO ${ }_{n}=$ Net operating income for the $\mathrm{n}$ period (includes sales minus all operating expenses, but does not include the financial results nor other non-operating income and expenses);

$\mathrm{AT}_{\mathrm{n}}=$ Total Assets in the $\mathrm{n}$ period. 
Equation 1:

$$
\begin{aligned}
& \Delta N I_{i t}=\alpha_{0}+\alpha_{1} S_{Z I Z} E_{i t}+\alpha_{2} \text { GROWTH }_{i t}+\alpha_{3} L E V_{i t}+\alpha_{4} D_{I S S U E_{i t}}+\alpha_{5} T U R N_{i t}+\alpha_{6} C F_{i t}+ \\
& +\alpha_{7} A U D_{i t}+\alpha_{8} X L I S T_{i t}+\alpha_{9} \operatorname{CLOSE}_{i t}+\varepsilon_{i t}
\end{aligned}
$$

Independent variables (of control):

SIZE = value of total assets;

GROWTH = percentage change in sales;

$\mathrm{LEV}=$ total liabilities divided by total equity at the end of the year;

DISSUE $=$ percentage change in total liabilities;

TURN = sales divided by total assets at the end of the year;

$\mathrm{CF}=$ annual net cash flow from operating activities divided by total assets at the end of the year;

$\mathrm{AUD}=$ dummy variable, with 1 being audited company by PwC, KPMG, E\&Y or D\&T, and zero for others;

XLIST $=$ trading of shares on the stock exchange in the United States of America, 1 for yes and zero for no;

CLOSE $=$ Percentage of shares held by individuals or entities related to the company, as directors and their families, foundations, among others.

The variability of $\Delta \mathrm{NI}$ is its variance of residuals of Equation 1, applied in the pre- and post-convergence. The smaller the variation, the greater the evidence of income smoothing (earnings management).

The EISSUE variable (percentage of changes in preferred shares), present in the model applied by Barth, Landsman and Lang (2008), was not used in this study. This variable is based on the model of Pagano, Röell and Zehner (2002), which assumes that the financing structure can influence business decisions on highlighted information. The study of Barth, Landsman and Lang (2008) was applied to companies from countries where the capital market is the main source of funding for companies. In Brazil, despite the development of the capital market in recent years, long-term debt have yet as the main source to financial institutions, especially government, such as BNDES. So to capture the effects of the financing structure in this study, we used the LEV and DISSUE variables. Measure 2: Mean rate 
variability in the changes in net income $(\Delta \mathrm{NI})$ on the variability of changes in Operating Cash Flow $(\triangle \mathrm{CFO})$.

Dependent variable:

$\Delta \mathrm{CFO}_{\mathrm{n}}$

$$
\Delta C F O=\left(\frac{C F O}{n}=\frac{C F O}{A-1}\right)
$$

Where:

$\mathrm{CFO}_{\mathrm{n}}=$ Operating cash flow in the $\mathrm{n}$ period;

$\mathrm{AT}_{\mathrm{n}}=$ Total Assets in the $\mathrm{n}$ period.

Equation 2:

$$
\begin{aligned}
& \Delta \text { CFO }_{i t}=\alpha_{0}+\alpha_{1} \text { SIZE }_{i t}+\alpha_{2} \text { GROWTH }_{i t}+\alpha_{3} L E V_{i t}+\alpha_{4} \text { DISSUE }_{i t}+\alpha_{5} T_{U R N_{i t}}+\alpha_{6} C F_{i t}+ \\
& +\alpha_{7} A U D_{i t}+\alpha_{8} X \operatorname{LIST}_{i t}+\alpha_{9} C L O S E_{i t}+\varepsilon_{i t}
\end{aligned}
$$

Independent variables (of control):

The same metric as 1 .

$$
\frac{\Delta N I}{\Delta C F O}=\left(\frac{\Delta N I}{\Delta C F O_{n}}\right)
$$

Where:

$\Delta \mathrm{NI}_{\mathrm{n}}=$ residual of equation 1 in the $\mathrm{n}$ period;

$\Delta \mathrm{CFO}_{\mathrm{n}}=$ residual of equation 2 in the $\mathrm{n}$ period.

The variability $\triangle \mathrm{CFO}$ is the variance of residuals from Equation 2 groups, the first group pre-convergence and the second, post-convergence. The smaller the variation, the greater the likelihood of GR.

Measure 3: Pearson correlation between accruals and cash flow

Dependent variables:

$$
\begin{aligned}
C F & =\frac{C F O}{A T}(3) \\
A C C & =\frac{(L O-C F O)}{A T}
\end{aligned}
$$

Where:

$\mathrm{ACC}=$ accruals

$\mathrm{LO}=$ operating net profit 
$\mathrm{CFO}=$ operating cash flow

$\mathrm{AT}=$ Total assets

Equation 3:

$$
\begin{aligned}
& C_{i t}=\alpha_{0}+\alpha_{1} S_{I Z E_{i t}}+\alpha_{2} \text { GROWTH }_{i t}+\alpha_{3} L_{E V} V_{i t}+\alpha_{4} \text { DISSUE }_{i t}+\alpha_{5} \text { TURN }_{i t}+ \\
& +\alpha_{6} A U D_{i t}+\alpha_{7} \text { XLIST }_{i t}+\alpha_{8} \operatorname{CLOSE}_{i t}+\varepsilon_{i t}
\end{aligned}
$$

Equation 4:

$$
\begin{aligned}
& A C C_{i t}=\alpha_{0}+\alpha_{1} \operatorname{SIZE}_{i t}+\alpha_{2} \text { GROWTH }_{i t}+\alpha_{3} L_{E V_{i t}}+\alpha_{4} \text { DISSUE }_{i t}+\alpha_{5} \text { TURN }_{i t}+ \\
& +\alpha_{6} \text { AUD }_{i t}+\alpha_{7} \text { XLIST }_{i t}+\alpha_{8} \operatorname{CLOSE}_{i t}+\varepsilon_{i t}
\end{aligned}
$$

Independent variables:

The same as metric 1 , excluding the $\mathrm{CF}$ variable.

$$
A C C_{-} C F_{n}=\rho(A C C, C F)
$$

Were compared correlations of the residuals of Equations 3 and 4, instead of correlations between $\mathrm{CF}$ and ACC, directly. A negative correlation is an indicator of GR, since companies tend to influence their accruals up when the cash flows appear smaller.

Data collection was carried out from the website of Thomson ONE Banker (http://banker.thomson.com), in Thomson Financial and Worldscope databases. The period of analysis ranged between:

a. $\quad 2005$ to 2007 - before the entry into force of Law N. 11.638/07, which brought profound changes in the Brazilian accounting standard-setting, in convergence with international accounting standards of the IASB;

b. 2010-2012 - adoption period of full IFRS for consolidated financial statements.

It was not considered in the analysis in 2008 due to two main aspects: regulatory and economic. On the first point, although Law N. 11.638/07, considered initial legal framework of the convergence of Brazilian accounting standards to the IASB standards, has entered into force in 2008, some of its provisions had their deferred application for 2009. In addition, by the end of 2008, the Comitê de Pronunciamentos Contábeis (CPC) had issued only 15 pronouncements. On the second aspect, the economic, remember that the year 2008 was marked by strong global economic crisis, which started in the United States with the real estate crisis, known as the subprime crisis, which led to the bankruptcy institutions financial and insurance companies known worldwide. This crisis spread worldwide, impacting the 
results of various companies. In the year 2008, was not considered in the 2009 analysis. First, because $\triangle \mathrm{NI}$ and $\triangle \mathrm{CFO}$ variables for 2009 are influenced by the 2008 values (range compared to the previous year). In addition, the year 2009 can still be considered as a transition period to IFRS.

\section{DATA DESCRIPTION AND ANALYSIS}

First, it presents the descriptive statistics for the test variables and control variables used in the regression equations, as shown in Table 1.

Table 1 - Descriptive Statistics of the Additional Data of Brazilian Companies

\begin{tabular}{c|c|c|c|c|c|c}
\hline \multirow{2}{*}{ Variables } & \multicolumn{3}{|c|}{ Period pre-IFRS (period 1) } & \multicolumn{2}{c}{ Period post-IFRS (period 2) } \\
\cline { 2 - 7 } & mean & Median & $\begin{array}{c}\text { Standard } \\
\text { deviation }\end{array}$ & mean & $\begin{array}{c}\text { Standard } \\
\text { deviation }\end{array}$ \\
\hline N I $\Delta$ & -0.0044 & -0.0013 & 0.0653 & -0.0035 & -0.0027 & 0.0400 \\
$\Delta$ C FO & -0.0067 & -0.0014 & 0.12589 & -0.0145 & -0.0044 & 0.12165 \\
ACC & -.0143 & 0.0054 & 0.25659 & 0.0038 & 0.0032 & 0.12932 \\
C F & 0.0462 & 0.0569 & 0.27513 & 0.0444 & 0.0448 & 0.16145 \\
\hline S IZE & 6.7398 & 6.4795 & 2.276 & 7.6105 & 7.3476 & 2.4003 \\
G ROWTH & 0.2005 & 0.1087 & 0.66589 & 0.2258 & 0.1128 & 1.8570 \\
L EV & 1.6960 & 1.1897 & 5.876 & 5.4192 & 1.4188 & 35.7096 \\
D ISSUE & 0.4599 & 0.1182 & 2.85705 & 0.1716 & 0.1046 & 0.4523 \\
T URN & 0.7769 & 0.6657 & 0.61422 & 0.6518 & 0.5313 & 0.5586 \\
C F & 0.0462 & 0.0569 & 0.27513 & 0.0444 & 0.0448 & 0.16145 \\
The UD & 0.6723 & 1.0000 & 0.47005 & 0.6836 & 1.0000 & 0.46577 \\
X LIST & 0.1793 & 0.0000 & 0.38412 & 0.1940 & 0.0000 & 0.39604 \\
C LOSE & 0.2172 & 0.0000 & 0.31848 & 0.2102 & 0.0000 & 0.2950 \\
\hline
\end{tabular}

$\Delta \mathrm{NI}=$ variability of changes in net income; $\triangle \mathrm{CFO}=$ variability of changes in Operating Cash Flow; ACC

= accruals; $\mathrm{CF}=$ cash flow; SIZE = natural logarithm of total assets; GROWTH = percentage of change in sales; LEV = total liabilities divided by total equity at the end of the year; DISSUE = percentage change in total liabilities; TURN = sales divided by total assets at the end of the year; $\mathrm{CF}=$ annual net cash flow from operating activities divided by total assets at the end of the year; AUD = dummy variable, with 1 being to audited company by PwC, KPMG, E\&Y or D\&T, and zero for others; XLIST = trading of shares on the stock exchange in the United States of America, 1 for yes and zero for no; CLOSE = Percentage of shares held by individuals or entities related to the company, as directors and their families, foundations, among others.

Source: research data.

The test variables shown in Table 1 demonstrate greater standard deviation in the preconvergence period, which may indicate that the results of the companies showed less variability in the post-convergence period, with income smoothing evidence.

However it is emphasized that this analysis of test variables should be treated with caution as they may be influenced by other external factors beyond the international accounting convergence process, which the model by Barth, Landsman and Lang (2008) seeks to mitigate with the use of control variables.

Regarding the control variables, firm size, measured by the natural logarithm of the total assets of the companies, showed an increase in the post-IFRS period. There was also an 
increase in average sales growth from the period 1 to period 2. It is also noted an increase in debt (LEV) in period 2. However, as the change in liabilities (DISSUE) shows a reduction in period 2, it appears that the increase in debt (LEV) may have been more due to the decrease in the value of net assets of businesses than by rising debts properly. Based on these variables, we calculated the three measures of GR in the model of Barth, Landsman and Lang (2008), from the four multiple linear regression equations already presented. Before the calculation of these measures, were tested the assumptions of linear regression of residual autocorrelation, the homoscedasticity, multicollinearity and normal distribution. The results show that the autocorrelation of the assumptions of residual (Durbin-Watson test) and multicollinearity (VIF test) were met, except for the assumption of homoscedasticity and normal distribution.

The problem of heteroscedasticity data was identified by the Test of White in Stata 11.2 software. To remedy it, we used robust regression in the same software. For normality of the data, given the sample size of 357 and 335 observations for periods 1 and 2, respectively, this assumption is relaxed in this analysis. Gujarati (2006) states that the assumption of normality is restricted to small samples (less than 100 observations) and may assume the normality assumption for larger samples based on the Central Limit Theorem (Teorema do Limite Central - TLC). According to Stevenson (2001, p. 181), by central limit theorem “[...] even in the case of a non-normal distribution, the distribution of the sample means will be approximately normal, since the sample is large." These results, according to Stevenson (2001), are known as Central Limit Theorem and represent one of the most important concepts related to statistical inference. The only restriction for its use is that the sample is greater than 30 observations.

The first measure of GR refers to the variability of income divided by total assets of each company, from one year to the next. According to Barth, Landsman and Lang (2008), significant variations in changes in income may be income smoothing earnings evidence. As the profit can be varied influenced by external factors and directly related to the accounting standards, the variable $\Delta \mathrm{NI}_{\mathrm{n}}$ was used as the dependent variable in the equation of regression 1 , which includes some control variables. The calculation of the GR level occurs from the variance of residuals of equation 1, operating profit variability place directly in order to mitigate external effects on variability of operating income. The results from the regression from equation 1 are shown in Table 2. 
Table 2 - Results of Regression of Equation 1

\begin{tabular}{|c|c|c|c|c|}
\hline Model 1 & \multicolumn{2}{|c|}{ Period pre-IFRS } & \multicolumn{2}{|c|}{ Period post-IFRS } \\
\hline $\mathrm{R}$ & & 0.241 & & 0.305 \\
\hline$R^{2}$ & & 0.058 & & 0.093 \\
\hline $\mathrm{R}^{2}$ adjusted & & 0.034 & & 0.068 \\
\hline Standard error of the estimate & & 0.06420 & & 0.03867 \\
\hline Durbin Watson & & 2.087 & & 1.628 \\
\hline Variance of Residuals & & 0.004 & & 0.001 \\
\hline $\bar{F}$ & & 2.377 & & 3.692 \\
\hline Sig & & 0.013 & & 0.000 \\
\hline $\mathrm{n}$ & & 357 & & 335 \\
\hline Variables & Coefficients & VIF & Coefficients & VIF \\
\hline $\mathrm{C}$ & -0.024 & & 0.001 & \\
\hline Size & $0.004^{* * *}$ & 2.338 & -0.001 & 2.308 \\
\hline Growth & $0.016^{*}$ & 1.271 & 0.000 & 1.021 \\
\hline Lev & 0.000 & 1.123 & 0.000 & 1.013 \\
\hline Dissue & $-0.004^{*}$ & 1.250 & -0.007 & 1.009 \\
\hline Turn & 0.010 & 1.197 & -0.007 & 1.123 \\
\hline $\mathrm{CF}$ & $-0.022^{* * * *}$ & 1.094 & 0.065 & 1.078 \\
\hline Aud & $-0.022^{* * *}$ & 1.509 & 0.002 & 1.551 \\
\hline Xlist & -0.004 & 1.500 & 0.000 & 1.536 \\
\hline Close & 0.000 & 1.170 & 0.000 & 1.089 \\
\hline \multicolumn{5}{|l|}{ a. Dependent varible: $\Delta \mathrm{NI}$} \\
\hline \multicolumn{5}{|c|}{ b. Forecasters: (Constant), size, close, lev, aud, growth, turn, xlist, cf, disuse } \\
\hline
\end{tabular}

It is observed in Table 2, that the model is significant in both periods, with explanatory power of $5.8 \%$ and $9.3 \%$, respectively. The residual value of the model used in the calculation of smoothing shows values of 0.004 (period 1) and 0.001 (period 2). These values were obtained from the variance of the set of observations residues. It was found the company by company residue and, as a result, we calculated the variance of this set of residue.

The control variables considered significant for explaining the variability of profits $(\triangle \mathrm{NI})$ in period 1 were of the size (SIZE) and cash flow (CF), 10\%; auditing (AUD) 5\%; and the change in liabilities (DISSUE) and sales growth (GROWTH) 1\%. In period 2, the significant variables were sales by total assets (TURN), 10\%; the percentage of shares held by individuals or entities related to the company (CLOSE), 5\%; and cash flow (CF) $1 \%$. The calculation of the second measure of GR takes into consideration the profit rate variability on the variability of cash flows, and $\Delta \mathrm{NI}$ the variance of residuals of equation 1 and $\triangle \mathrm{CFO}$ the variance of residuals of the equation 2 .

Barth, Landsman and Lang (2008) argue that firms with higher volatility in cash flow typically have higher volatility in net income. This second measure attempts to control this factor. If companies use accruals to manage results, the variability of changes in net income 
may be less than the variability of changes in operating cash flow. The results of the equation of the regression 2 are shown in Table 3.

Table 3 - Results of the Regression of Equation 2

\begin{tabular}{|c|c|c|c|c|}
\hline Model 2 & \multicolumn{2}{|c|}{ Period pre-IFRS } & \multicolumn{2}{|c|}{ Period post-IFRS } \\
\hline $\mathrm{R}$ & & 0.380 & & 0.783 \\
\hline $\mathrm{R}^{2}$ & & 0.145 & & 0.613 \\
\hline $\mathrm{R}^{2}$ adjusted & & 0.122 & & 0.603 \\
\hline Standard error of the estimate & & 0.11794 & & 0.07670 \\
\hline Durbin Watson & & 1.823 & & 1.986 \\
\hline Variance of Residuals & & 0.014 & & 0.006 \\
\hline $\mathrm{F}$ & & 6.514 & & 57.254 \\
\hline Sig & & 0.000 & & 0.000 \\
\hline $\mathrm{N}$ & & 357 & & 335 \\
\hline Variables & Coefficients & VIF & Coefficients & VIF \\
\hline $\mathrm{C}$ & 0,020 & & -0.062 & \\
\hline Size & -0.006 & 2.338 & $0.006^{* *}$ & 2.308 \\
\hline Growth & 0.013 & 1.271 & -0.001 & 1.021 \\
\hline Lev & 0.002 & 1.123 & 0.000 & 1.013 \\
\hline Dissue & $-0.005^{* *}$ & 1.250 & -0.006 & 1.009 \\
\hline Turn & $-0,005$ & 1.197 & -0.013 & 1.123 \\
\hline $\mathrm{CF}$ & $0.164^{*}$ & 1.094 & $0.579^{*}$ & 1.078 \\
\hline Aud & -0.001 & 1.509 & -0.015 & 1.551 \\
\hline Xlist & 0.003 & 1.500 & -0.018 & 1.536 \\
\hline Close & 0.000 & 1.170 & 0.000 & 1.089 \\
\hline
\end{tabular}

a. Dependent Varible: $\triangle \mathrm{CFO}$

b. Forecasters: (Constant), size, close, lev, aud, growth, turn, xlist, cf, dissue

"significant at $1 \%$. significant at 5\%. ${ }^{* * * *}$ significant at $10 \%$.

Source: research data.

Table 3 shows that the model is significant for two periods, with $14 \%$ of explaining power for one period and $61 \%$ for the period 2. The variance of results used for calculation of the smoothed model, is 0.014 (period 1) and 0.006 (period 2).

The control variables considered significant variability explanation of operating cash flows $(\triangle \mathrm{CFO})$ were cash flow of business (CF) in both periods, the change in liabilities (DISSUE) in period 1 and the size (SIZE) 2 in the period.

The second GR metric is the division of the variability of changes in operating profit on the variability of changes in cash flow, with the following value for the two periods:

Pre-IFRS: $-\frac{\Delta N I_{n}}{\Delta C F \bar{O}_{n}}-\left(\begin{array}{l}0,004 \\ 0,014\end{array}\right)=0,29$
Post-IFRS

$\frac{\Delta N I_{n}}{\Delta C F O_{n}}-\left(\begin{array}{l}0,001 \\ 0,006\end{array}\right)-\cap 17$

The third measure of GR is based on the Pearson correlation between accruals (ACC) and cash flows $(\mathrm{CF})$. As in the previous two steps, are compared the residues of equations 3 
and 4, instead of correlations between ACC and CF directly. The control variables are the same used in equations 1 and 2, except for CF variable, which is treated as a dependent variable in the equation 3. The value of accruals, following the model of Barth, Landsman and Lang (2008), is calculated as the difference between operating income and operating cash flow divided by total assets.

According to Iatridis and Rouvolis (2010), a negative correlation is an indicator of GR, since companies tend to influence their accruals up when the cash flows appear smaller. The results of equation 3 are shown in Table 4.

Table 4 - 3 of the Equation Regression Results

\begin{tabular}{|c|c|c|c|c|}
\hline Model 3 & \multicolumn{2}{|c|}{ Per iodo pre-IFRS } & \multicolumn{2}{|c|}{ Per iodo post-IFRS } \\
\hline $\mathrm{R}$ & & 0.292 & & 0.268 \\
\hline $\mathrm{R}^{2}$ & & 0.086 & & 0.072 \\
\hline $\mathrm{R}^{2}$ adjusted & & 0.065 & & 0.049 \\
\hline Standard error of the estimate & & 0.26611 & & 0.15743 \\
\hline Durbin Watson & & 1.987 & & 1.977 \\
\hline Variance of Residuals & & 0.071 & & 0.025 \\
\hline $\mathrm{F}$ & & 4.069 & & 3.160 \\
\hline Sig & & 0.000 & & 0.002 \\
\hline $\mathrm{N}$ & & 357 & & 335 \\
\hline Variables & Coefficients & VIF & Coefficients & VIF \\
\hline $\mathrm{C}$ & -0.243 & & -0.110 & \\
\hline Size & $0.032^{*}$ & 2.263 & $0.018^{*}$ & 2.234 \\
\hline Growth & -0.013 & 1.270 & $-0.009^{* * *}$ & 1.009 \\
\hline Lev & 0.000 & 1.123 & 0.000 & 1.012 \\
\hline Dissue & -0.003 & 1.249 & -0.011 & 1.008 \\
\hline Turn & $0.090^{*}$ & 1.153 & $0.042^{*}$ & 1.100 \\
\hline Aud & 0.007 & 1.509 & 0.004 & 1.551 \\
\hline Xlist & -0.042 & 1.496 & -0.026 & 1.532 \\
\hline Close & 0.001 & 1.165 & 0.000 & 1.089 \\
\hline \multicolumn{5}{|l|}{ a. Vari ble dependent: $\mathrm{CF}$} \\
\hline \multicolumn{5}{|c|}{ b. Forecasters: (Constant), size, close, lev, aud, growth, turn, xlist, disuse } \\
\hline
\end{tabular}

Equation 3 uses as the dependent variable cash flow (CF). Table 4 shows the model of equation 3 as mean in the two study periods, the clarification of $8.6 \%$ and $7.2 \%$ in each period, respectively. It is observed that in the period 1, the variable that helps explain the $\mathrm{CF}$ companies, significantly, is the size of the companies (SIZE) and sales divided by assets (TURN). In the period 2, the significant variables were size (SIZE), sales growth (GROWTH) and sales of assets (TURN). Table 5 presents the results of the regression of the equation 4.

Table 5 - Results of the Regression of Equation 4

\begin{tabular}{l|r|r}
\hline Model 4 & Period pre-IFRS & \multicolumn{1}{|c}{ Period post-IFRS } \\
\hline $\mathrm{R}$ & 0.097 & 0.154 \\
\hline
\end{tabular}




\begin{tabular}{|c|c|c|c|c|}
\hline$R^{2}$ & & 0.009 & & 0.024 \\
\hline $\mathrm{R}^{2}$ adjusted & & -0.013 & & 0.000 \\
\hline Standard error of the estimate & & 0.25829 & & 0.12934 \\
\hline Durbin Watson & & 2.005 & & 2.091 \\
\hline Variance of Residuals & & 0.067 & & 0.017 \\
\hline $\mathrm{F}$ & & 0.415 & & 0.983 \\
\hline Sig & & 0.911 & & 0.449 \\
\hline $\mathrm{n}$ & & 357 & & 335 \\
\hline Variables & Coefficients & VIF & Coefficients & VIF \\
\hline $\mathrm{C}$ & 0.059 & & 0,001 & \\
\hline Size & -0.008 & 2.263 & -0.003 & 2.234 \\
\hline Growth & 0.016 & 1.270 & 0.006 & 1.009 \\
\hline Lev & 0.000 & 1.123 & 0.000 & 1.012 \\
\hline Dissue & 0.001 & 1.249 & 0.008 & 1.008 \\
\hline Turn & -0.010 & 1.153 & -0.004 & 1.100 \\
\hline$\overline{\text { Aud }}$ & 0.034 & 1.509 & $0.033^{* * *}$ & 1.551 \\
\hline Xlist & 0.014 & 1.496 & -0.010 & 1.532 \\
\hline Close & 0.000 & 1.165 & 0.000 & 1.089 \\
\hline \multicolumn{5}{|l|}{ a. Vari ble dependent: ACC } \\
\hline \multicolumn{5}{|c|}{ b. Forecasters: (Constant), size, close, lev, aud, growth, turn, xlist, disuse } \\
\hline
\end{tabular}

Equation 4 considers as the dependent variable accruals. The model presented in Table 5 is not significant in both periods, with explanatory power of $1 \%$ and $2 \%$, respectively. No tested variable is significant to explain the value of accruals (ACC) in period 1. The ACC is explained significantly in period 2 by the variable accounting firm (AUD), but only $10 \%$. To reach the third measure of the GR model of Barth, Landsman and Lang (2008), we calculate the Pearson correlation between the residuals of the equations 3 and 4 . If the correction coefficient is negative and significant, there are signs of GR through the use of accruals in order to align the result to the company's cash flow.

Table 6 - Pearson Correlation Between Residues of Equations 3 and 4

\begin{tabular}{c|c|c|c}
\hline Varible 1 & Varible 2 & \# Cases & Correlation Coefficient \\
\hline $\operatorname{ResCF}_{\mathrm{t} 1}$ & $\operatorname{ResAcc}_{\mathrm{t} 1}$ & 357 & $-0.911^{*}$ \\
\hline $\operatorname{ResCF}_{\mathrm{t} 2}$ & $\operatorname{ResAcc}_{\mathrm{t} 2}$ & 335 & $-0.758^{*}$ \\
\hline
\end{tabular}

$\operatorname{ResCF}_{\mathrm{T}}=$ residue of equation $3 ; \operatorname{ResAcc}_{\mathrm{t}}=$ residues of the equation 4.

* Significant at $1 \%$

Source: research data.

It is shown in Table 6 that the Pearson correlation coefficient between the cash flow (CF) and accruals (ACC) was negative in both study periods, indicating that there GR evidence in both periods. However, considering that the equation 4 is not significantly, we denote their residues $\left(\operatorname{ResAcc}_{\mathrm{t}}\right)$ not only represent the effect of the adoption of IFRS, but also other variances in accruals not explained by the model. Thus, the results of measurement of the third GR cannot be considered to address the problem of search. Table 7 presents a 
summary of the three GR measures tested in the pre-IFRS period (2005-2007) and post-IFRS period (2010-2012), along with the $\mathrm{F}$ test for the differences in these measures between the two study periods.

Table 7 - Comparative of GR Level in Brazilian Companies

\begin{tabular}{l|c|c|c|c|c}
\hline \multicolumn{1}{c|}{ GR Metrics } & $\begin{array}{c}\text { Forecasts } \\
\text { Template }\end{array}$ & $\begin{array}{c}\text { Post-IFRS } \\
(\text { Period 2) }\end{array}$ & $\begin{array}{c}\text { Pre-IFRS (period } \\
1)\end{array}$ & Statics F & P-value \\
\hline$\Delta$ NI & $\mathrm{p} 2>\mathrm{p} 1$ & 0.001 & 0.004 & 2.7605 & 0.000 \\
\hline $\mathrm{NI} \Delta / \Delta \mathrm{CFO}$ & $\mathrm{p} 2>\mathrm{p} 1$ & 0.17 & 0.29 & 8.5834 & 0.000 \\
\hline $\begin{array}{l}\text { ACC and CF Correlation } \\
\text { (Pearson) }\end{array}$ & $\mathrm{p} 2>\mathrm{p} 1$ & $-0.758^{*}$ & $-0.911^{*}$ & & \\
\hline
\end{tabular}

Note: " significant correlation coefficient at $1 \%$.

Source: research data.

It is observed in Table 7 , the profit variability $(\Delta \mathrm{NI})$ and the variability of the profit rate on operating cash flow $(\Delta \mathrm{NI} / \Delta \mathrm{CFO})$ have lower rates in period 2 regarding period 1 , and these results are contrary to the assumption in the model of Barth, Landsman and Lang (2008). This indicates that there was less variability in income compared to operating cash flow of the companies in the post-IFRS period (2010-2012), which indicates an increase in income smoothing practices after convergence.

Regarding the third measure of GR, correlation between ACC and $\mathrm{CF}$, it presents coefficient of negative and significant correlation in both periods. However, as the result of equation 4 (Table 5) was not significant, it is not possible to make inferences about the results of management practices based on that third metric. To determine the significance of the differences found in the first two GR measures, the F test was used on residues from the equations 1 and 2 . Both $(\triangle \mathrm{NI}$ and $\Delta \mathrm{NI} / \triangle \mathrm{CFO})$ showed significant differences between the periods, with P-value equal to zero.

These results are also different from those observed by Santos et al. (2011), who found no change in the degree of conservatism of the first quarter of 2005 and the third quarter of 2009. It also do not support the study of Grecco (2013), who found no changes in the level of earnings management of 361 Brazilian non-financial companies in the 2005 to 2011 period. However, it is important to note that these studies show some differences regarding this, as the analysis period, the object of analysis, accounting conservatism in the case of Santos et al. (2011) and the results used management model (Jones Modified), in the case of Grecco (2013).

Regarding the study Grecco (2013), the Modified Jones model calculates earnings management based on accruals discretionary. It used as control variables the variation in income and investment in fixed assets. However this model receives criticism for pointing 
specification errors in companies with very high or very low profits and cash flows (DECHOW; SLOAN; SWEENEY, 1995). In addition, Kang and Sivaramakrishnan (1995) noted the omission of a variable that refers to the cost of sales and expenses, as they are not perfectly correlated with income. Such problems are relatively common in models that try to capture the discretionary part of accruals.

The model used in this study, based on the applied by Barth, Landsman and Lang (2008) does not calculate GR based on the discretionary accrual. Instead, it choose to determine smoothing practices of results based on variations in profit, cash flow and its relationship with the total accruals. So they are conceptually different ways to determine GR, which may explain the differences in results between this study and the Grecco (2013).

The results of this study are relevant in the Brazilian economic/legal context by pointing the need for expansion of enforcement mechanisms, to ensure the fully application of international accounting standards. This means that there is possibility of a convergence of right, but not effective. The discussion of the extent to which the IASB standards are being implemented effectively and not only to fulfill a legal requirement should be noteworthy in academia.

It is also possible that the increase in GR levels observed in the study is the result of a process of adaptation of Brazilian professionals to accounting standards established based on principles rather than rules. This process takes time to be completed and so that the expected benefits of convergence, especially improving the quality of accounting information, are achieved only in the future. However the Brazilian regulatory agencies need to be aware of this process, to ensure we have in Brazil a full convergence with international accounting standards.

\section{CONCLUSIONS}

The study aimed to investigate the influence of convergence with international accounting standards of the IASB in smoothing levels in Brazilian companies. Research with quantitative approach, based on the model of Barth, Landsman and Lang (2008), was carried out of the financial statements of 123 companies in the period 2005-2007 (pre-IFRS) and 2010-2012 (post-IFRS) totaling 357 observations in the pre and 335 comments in the postIFRS period. The first measure of GR used, variability in profit, showed the greatest variation in the pre-IFRS period, representing greater smoothing evidence in the results after convergence. The income smoothing is treated in the literature as proxy of GR. According to Lang et al. (2003), Leuz, Nanda and Wysocki (2003), Ball and Shivakumar (2005; 2006), 
Lang, Raedy and Wilson (2006) and Barth, Landsman and Lang (2008), companies with less income smoothing show greater volatility in income and hence lower the GR level.

The second measure of GR used in the study also had a higher ratio of profit and operating cash flow in the pre-convergence period. According to Barth, Landsman and Lang (2008) and Iatridis (2010), this fact may indicate the practice of smoothing in postconvergence periods. It means that companies used accruals after convergence, causing the variability of income $(\Delta \mathrm{NI})$ in relation to cash flow was lower than that observed in the preconvergence period.

The third measure of GR, characterized by the correlation between operating cash flow and accruals, showed no significant results for the equation 4, which deals with accruals (ACC). Thus, it is not possible to state whether there was increased use of accruals and hence greater GR, after convergence. The literature suggests that the lower the cash flow of the companies, the greater the use of accruals. Lang et al. (2003), Leuz, Nanda and Wysocki (2003), Ball and Shivakumar (2005; 2006), Lang, Raedy and Wilson (2006), Barth, Landsman and Lang (2008) and Iatridis (2010) state that companies with the restriction cash flow may use accruals to reduce its results. From the results of the first two GR measures, it is concluded that, in Brazilian companies, the process of convergence to the accounting standards of the IASB, more flexible and principled rather than standards, resulted, at least at first, in elevated levels of smoothing results shown by companies. It is possible that the greater flexibility of current standards has increased the discretion of the preparer of the financial statements. This may have used its power to manage results in order to achieve its own goals at the expense of other users of accounting information.

This result is consistent with studies of Goncharov and Zimmermann (2006) and Paananen and Lin (2009), both in German companies, which showed increase in GR after the adoption of IFRS. Also consistent with the study of Iatridis and Rouvolis (2010), which indicated elevation of GR in Greek companies after convergence. But is divergent results found in some studies with Brazilian companies, such as Santos et al. (2011) on accounting conservatism, and Grecco (2013) on management. It appeared that there are still differences between the national studies on the effects of the adoption of IFRS in the quality of accounting information disclosed by Brazilian companies.

However, as the international accounting convergence process in Brazil is still recent, it may not be fully consolidated, particularly in terms of adaptation of financial statements preparers to the new rules. Thus it is possible that in the future, the higher quality of the IASB 
standards advocated in the various studies presented here, together with the adaptation of contextual characteristics of Brazil to those standards, resulting in improving the quality of accounting information evidenced by companies through reducing levels of GR.

The survey results do not allow rejecting the first hypothesis of the study research: $\mathrm{H}_{1}$ the process of convergence with international accounting standards increased the earnings management in Brazilian companies. On the other hand, rejects the hypothesis $2: \mathrm{H}_{2}$ - the process of convergence with international accounting standards decreased earnings management in Brazilian companies.

The conclusion is based on the study conducted, the effectiveness of the convergence of accounting standards from one country to the international standards of the IASB, in order to obtain better quality of accounting information, depends not only on convergence of accounting standards. It is necessary that the country was also concerned about the adequacy of legislation, investment in protecting the investors, good corporate governance practices, professional training and improve the quality of accounting education. Without investing in accounting education, we run the risk of having a set of accounting standards of excellent quality, but no professionals able to use them competently.

As the main limitations of the study, one can cite the model used by Barth, Landsman and Lang (2008). Although regularly cited in the literature on the subject, using various smoothing measures and work with control variables, that minimize the environmental effects on the GR measures, excluding other GR measures in the literature that can lead to different results. In addition, the authors themselves do not ensure that the control variables used in the model may fully neutralize all environmental influences on the results. Another limitation is related to the Operating cash flow variable (CFO). Before the Law N. 11.638/07, was not required to produce the Cash Flow Statement (DFC) by Brazilian companies. The CFO variable was taken directly from the Thomson One Banker database. However there may be difference in the composition of this variable before and after the entry into force of the law.

\section{REFERENCES}

ASHBAUGH, Hollis; OLSSON, Per. An exploratory study of the valuation properties of cross-listed firms' IAS and U.S. Gaap earnings and book values. The Accounting Review, v. 77, n. 1, p. 107-126, 2002.

ASHBAUGH, Hollis; PINCUS, Morton. Domestic Accounting Standards, International accounting standards and the predictability of earnings. Journal of Accounting Research, v. 39, n. 3, p. 417-434, 2001. 
BALL, Ray; SHIVAKUMAR, Lakshmanan. Earnings quality in UK private firms: comparative recognition timeliness. Journal of Accounting \& Economics, v. 39, n. 1, p. 83$128,2005$.

BALL, Ray; SHIVAKUMAR, Lakshmanan. The role of accruals in asymmetrically timely gain and loss recognition. Journal of Accounting Research, v. 44, n. 2, p. 207-249, 2006.

BARTH, Mary E.; LANDSMAN, Wayne R.; LANG, Mark H. International Accounting standards and accounting quality. Journal of Accounting Research, v. 46, n. 3, p. 467-498, 2008 .

BENEISH, Messod D.; YOHN, Teri Lombardi. Information friction and investor bias: a perspective on the effect of global IFRS adoption on the extent of equity home bias. Journal of Accounting and Public Policy, v. 27, p. 433-443, 2008.

BURGSTAHLER, David; DICHEV, Ilia. Earnings management to avoid earnings decreases and losses. Journal of Accounting and Economics, v. 24, p. 99-126, 1997.

CAVALIER-ROSA, Regina; TIRAS, Samuel L. Adoção do IFRS no Brasil: um terreno fértil para pesquisa sobre gerenciamento de resultados. Brazilian Business Review, v, 10, n. 4, p. 141-156, 2013.

CHEN, Huifa; TANG, Qingliang; JIANG, Yihong; LIN, Zhijun. The role of accounting standards: evidence from the European Union. Journal of International Financial Management \& Accounting, v. 21, n. 3, p. 1-57, 2010.

CHRISTENSEN, Hans B.; LEE, Edward; WALKER, Martin. Cross-sectional variation in the economic consequences of international accounting harmonization: the case of mandatory IFRS adoption in the UK. The International Journal of Accounting, v. 42, p. 341-379, 2007.

CHRISTENSEN, Hans B.; LEE, Edward; WALKER, Martin. Incentives or standards: what determines accounting quality changes around IFRS adoption? Working Paper, Manchester Accounting and Finance Group and Manchester Business School, 2008.

DASKE, Holger; HAIL, Luzi; LEUZ, Christian; VERDI, Rodrigo. Mandatory IFRS reporting around the world: early evidence on the economics consequences. Journal of Accounting Research, v. 46, n. 5, p. 1085-1142, 2008.

DECHOW, Patricia M.; SLOAN, Richard G.; SWEENEY, Amy P. Detecting earnings management. The Accounting Review. v. 70, n. 2, p. 193-225, 1995.

DING, Yuan; SU, Xijia. Implementation of IFRS in a regulated market. Journal of Accounting and Public Policy, v. 27, p. 474-479, 2008.

DYCK, Alexander; ZINGALES, Luigi. Private benefits of control: an international comparison. The Journal of Finance, v. 59, n. 2, p. 537-600, 2004.

ELBANNAN, Mohamed A. Accounting and stock market effects of international accounting standards adoption in an emerging economy. Review of Quantitative Finance and Accounting, v. 36, n. 2, p. 207-245, 2011. 
ERNSTBERGER, Jürgen; VOGLER, Oliver. Analyzing the German accounting triad "accounting premium" for IAS/IFRS and U.S. GAAP vis-à-vis German GAAP? The International Journal of Accounting. v. 43, p. 339-386, 2008.

GONCHAROV, Igor; ZIMMERMANN, Jochen. Do accounting standards influence the level of earnings management? Evidence from Germany. Working Paper, 2006. Disponível em: <http://papers.ssrn.com/sol3/papers.cfm?abstract_id=386521>. Acesso em: 22 abr. 2010.

GRECCO, Marta C. P. O efeito da convergência brasileiras às IFRS no gerenciamento de resultados das empresas abertas brasileiras não financeiras. Brazilian Business Review, v. 10, n. 4, p. 117-140, 2013.

GUJARATI, Damodar N. Econometria básica. 4. ed. São Paulo: Campus Books, 2006.

HEALY, Paul M.; WAHLEN, James M. A review of the earnings management literature and its implications for standard setting. Accounting Horizons, v. 13, p. 365-383, 1999.

IATRIDIS, George. International financial reporting standards and the quality of financial statement information. International Review of Financial Analysis, v. 19, n. 3, p. 193-204, 2010.

IATRIDIS, George; ROUVOLIS, Sotiris. The post-adoction effects of the implementation of international financial reporting standards in Greece. Journal of International Accounting, Auditing and Taxation, v. 19, p. 55-65, 2010.

JEANJEAN, Thomas; STOLOWY, Hervé. Do accounting matters? An exploratory analysis of earnings management before and after IFRS adoption. Journal of Accounting and Public Policy, v. 27, p. 480-494, 2008.

JONES, Jeniffer J. Earnings management during import relief investigations. Journal of Accounting Research, v. 29, n. 2, p. 193-228, 1991.

KANG, Sok-Hyon; SIVARAMAKRISHNAN, K. Issues in testing earnings management and an instrumental variable approach. Journal of Accounting Research. Oxford, v. 33, n. 2, p. 353-367, aut. 1995.

LANG, Mark; RAEDY, Jana Smith; YETMAN, Michelle Higgings. How representative are firms that are cross-listed in the United States? An analysis of accounting quality. Journal of Accounting Research, v. 41, n. 2, p. 363-397, 2003.

LANG, Mark; RAEDY, Jana S.; WILSON, Wendy. Earnings management and cross listing: are reconciled earnings comparable to us earnings? Journal of Accounting and Economics, v. 42, n. 1/2, p. 255-338, 2006.

LEUZ, Christian; NANDA, Dhananjay; WYSOCKI, Peter D. Earnings management and investor protection: an international comparison. Journal of Financial Economics, v. 69, n. 3, p. 505-528, 2003.

MARTINEZ, Antonio Lopo. Gerenciamento dos resultados contábeis: estudo empírico das companhias abertas brasileiras. 2001. 153f. Tese (Doutorado em Ciências Contábeis) Universidade de São Paulo, São Paulo, 2001. 
PAANANEN, Mari; LIN, Henghsiu. The development of accounting quality of IAS and IFRS over time: the case of Germany. Journal of International Accounting Research, v. 8, n. 1, p. 31-55, 2009.

PAGANO, Marco; RÖELL, Ailsa A.; ZEHNER, Josef. The geography of equity listings: why do companies list abroad? Journal of Finance, v. 57, p. 2379-2856, 2002.

PAULO, Edilson. Manipulação das informações contábeis: uma análise teórica e empírica sobre os modelos operacionais de detecção de gerenciamento de resultados. 2007. 260f. Tese (Doutorado em Ciências Contábeis) - Universidade de São Paulo, São Paulo, 2007.

RENDERS, Annelies; GAEREMYNCK, Ann. The impact of legal and voluntary investor protection on the early adoption of international financial reporting standards (IFRS). The Economist, v. 155, n. 1, p. 49-72, 2007.

SANTOS, Ariovaldo dos; PAULO, Edílson. Diferimento das perdas cambiais como instrumento de gerenciamento de resultados. Brazilian Business Review, v. 3, n. 1, p. 15-31, 2006.

SANTOS, Luis Paulo G. dos; LIMA, Gerlando A. S. F. de; FREITAS, SHEIZI C. de; LIMA, Iran S. Efeito da Lei 11.638/07 sobre o conservadorismo condicional das empresas listadas BM\&FBOVESPA. Revista de Contabilidade \& Finanças - USP, v. 22, n. 56, p. 174-188, maio/ ago. 2011.

SCHIPPER, Katherine. Earnings management. Accounting Horizons, v. 3, n. 4, p. 91-102, 1989.

STEVENSON, William J. Estatística aplicada à administração. São Paulo: Harbra, 2001 .

TRAPP, Adriana C.G. A relação do conselho fiscal como componente do controle no gerenciamento de resultados contábeis. 2009. 133f. Tese (Doutorado em Ciências Contábeis) - Universidade de São Paulo, São Paulo, 2009.

VAN TENDELOO, Brenda; VANSTRAELEN, Ann. Earnings management under German GAAP versus IFRS. European Accounting Review, v. 14, n. 1, p. 155, 2005.

WATTS, Ross L.; ZIMMERMANN, Jerold L. Positive accounting theory. Englewood Cliffs: Prentice Hall, 1986.

YOON, Sora. Accounting quality and international accounting convergence. 2007, $107 \mathrm{f}$., Tese (Doctor of Philosophy) - Oklahoma State University, 2007. 